\title{
Plant PHR Transcription Factors: Put on A Map
}

\author{
Paweł Sega $₫$ and Andrzej Pacak *10 \\ Department of Gene Expression, Institute of Molecular Biology and Biotechnology, Faculty of Biology, \\ Adam Mickiewicz University, Poznań, Uniwersytetu Poznańskiego 6, 61-614 Poznań, Poland; \\ p.sega@amu.edu.pl \\ * Correspondence: apacak@amu.edu.pl; Tel.: +48-618-295-955
}

Received: 24 October 2019; Accepted: 5 December 2019; Published: 6 December 2019

\begin{abstract}
The phosphate starvation response (PHR) protein family exhibits the MYB and coiled-coil domains. In plants, within the either $5^{\prime}$ untranslated regions (UTRs) or promoter regions of phosphate starvation-induced (PSI) genes are characteristic cis-regulatory elements, namely PHR1 binding sequence (P1BS). The most widely studied PHR protein family members, such as AtPHR1 in Arabidopsis thaliana (L.) and OsPHR2 in Oryza sativa (L.), may activate the gene expression of a broad range of PSI genes by binding to such elements in a phosphate (Pi) dependent manner. In Pi signaling, PHR transcription factors (TFs) can be selectively activated or deactivated by other proteins to execute the final step of signal transduction. Several new proteins have been associated with the AtPHR1/OsPHR2 signaling cascade in the last few years. While the PHR TF transcriptional role has been studied intensively, here we highlight the recent findings of upstream molecular components and other signaling pathways that may interfere with the PHR final mode of action in plants. Detailed information about transcriptional regulation of the AtPHR1 gene itself and its upstream molecular events has been reviewed.
\end{abstract}

Keywords: PHR1; phosphate signaling; protein-protein interactions; post-translational modifications

\section{Introduction}

Phosphorus $(\mathrm{P})$ is an essential element for all living organisms. Plants acquire $\mathrm{P}$ as inorganic phosphate (Pi) ions. An insufficient $\mathrm{P}$ level in the soil is one of the most limiting factors determining crop yield and productivity. Pi rock has been mined since the late 19th century and has been used as a main source of phosphate fertilizers worldwide [1,2]. Food production experiences the effects of climate change in the form of erosion patterns that influence the pollution of surface waters, with P causing eutrophication. $\mathrm{P}$ is not easily available in nature because of its immobility and high reactivity with soil constituents. Thus, environmental and industrial impacts on $P$ recycling prompt the development of balanced food production and sustainable P consumption. However, without understanding the ways in which P metabolism is regulated in eukaryotic cells, such technological efforts may not be used effectively.

The maintenance of $\mathrm{P}$ homeostasis in plants is strictly controlled by a molecular network regulated by a group of transcription factors (TFs). Generally, P-starved plants turn on local and long-distance signals to absorb and utilize $P$ from either internal or external pools. Thus, the inability of live organisms to adequately adapt to $\mathrm{P}$ limitation allows the possibility to screen genotypes or isolate mutants for functional genomic studies. The story of $\mathrm{P}$ homeostasis regulators began two decades ago with the characterization of green alga Chlamydomonas reinhardtii (Dangeard) phosphorus-starvation response 1 (PSR1) mutants exhibiting abnormality in their response to P deprivation. Shimogawara et al. identified two mutants, psr1-1 and psr1-2, that were defective in the synthesis of extracellular phosphatases and were unable to increase the rate of inorganic phosphate ion transport upon Pi scarcity [3]. They 
demonstrated that both mutants possess alterations in the same gene, named PSR1, and such variations are recessive and allelic [3]. Later, the PSR1 gene product was further investigated and has been recognized as a central transcriptional regulator that is needed to activate specific responses to $\mathrm{P}$ limitation [4,5]. Subsequent studies with higher plants revealed homologous genes, phosphate starvation response 1 (PHR1) in Arabidopsis thaliana (L.) [6], and phosphate starvation response 2 (PHR2) in Oryza sativa (L.) [7], which is orthologue of the AtPHR1 gene. Overexpression of AtPHR1 leads to increased Pi level in the shoot tissues, together with induction of several Pi starvation-induced (PSI) genes that encode phosphate transporters, phosphatases, or RNases [8,9]. While knockout of the AtPHR1 gene leads to defective accumulation of anthocyanin, starch, and sugar, alteration in the root architecture and impaired induction of multiple genes are known responses to Pi scarcity [10,11]. While the transcriptional regulation of many PSI genes by PHR1 TF is clear, the mechanism regulating the PHR1 transcript level and protein activity itself still remains largely unexplored.

Many components of the complex molecular networks are still missing. Thus, here we would like to highlight the most important findings on the PHR-like protein family and PSI gene expression regulation that may determine low-Pi tolerance in crop plants.

\section{PHRs Redundancy and Dimerization}

Among the eukaryotes, high functional redundancy of transcription factors is a phenomenon that is known to lead to one TF compensating for another, masking the TF knockout effect on the binding targets [12,13]. PHR-like proteins belong to the MYB-coiled-coil (MYB-CC) family of transcription factors, which are encoded by 15 genes in Arabidopsis, and as dimers bind an imperfect palindromic sequence (PHR1 binding sequence (P1BS); GnATATnC) $[6,14,15]$. Characteristic P1BS cis-regulatory motifs may be found either in the promoter or $5^{\prime}$ untranslated regions (UTRs) of the target genes, where PHR1 TF binds acting as an activator or repressor of transcription [16,17]. Apart from AtPHR1, other MYB-CC family members were found in recent studies in Arabidopsis: PHL1 (PHR1-like 1) [11], PHL2 and PHL3 [18], as well as PHL4 [19]. First remarks about PHR1 functional redundancy were found in phr1 phl1 double mutant in Arabidopsis. The loss-of-function double mutation only partially affected the transcription of PSI genes indicating the synergistic effect of PHR1/PHL1 genes and involvement of other PHR-like TFs [11].

\subsection{Cooperation between PHR Family Members}

In particular, studies in various plant species demonstrated the widespread species-specific functions of PHR-like TFs. Overexpression of TaPHR1 resulted in upregulation of a subset of PSI genes following the stimulation of lateral root branching and overall grain yield promotion of Triticum aestivum (L.) plants under Pi scarcity [20]. On the contrary, overexpression of BnPHR1 caused Pi accumulation in shoots and retarded growth of Brassica napus (L.) plants [21]. Relevant work in rice has disclosed a few more AtPHR1 orthologues, such as OsPHR1, OsPHR2, OsPHR3 [7,22], and OsPHR4 [23]. In 2015, Guo et al. showed that the expression of OsPHR3 gene was induced under Pi starvation, but not that of OsPHR1/2 [22]. Additionally, all three OsPHRs exhibit different DNA-binding affinity properties, and only plants with overexpression of OsPHR3 gene exhibited low-Pi stress tolerance under field conditions. They proved that functional redundancy exists between OsPHR1, OsPHR2, and OsPHR3 proteins and such diversity enables them to co-regulate Pi response in rice [22]. Further, it was shown that similar to OsPHR3, OsPHR4 is a Pi starvation-induced gene and its expression is directly regulated by OsPHR1/2/3, which can all bind to the P1BS elements located in the OsPHR4 promoter [23]. Interestingly, OsPHR4 could also bind to its own promoter in this study.

\subsection{PHRs Work Together in a Link}

Beside PHR redundancy, dimerization itself is a crucial step for PHR-like TF DNA binding capability. Previous reports showed that AtPHR1 forms heterodimers with AtPHL1 [11], and the interaction of AtPHL2 and AtPHL3 was also observed, and both can homodimerize [18]. Likewise, 
Ruan et al. showed that OsPHR4 could form a heterodimer with either OsPHR1, OsPHR2, or OsPHR3, as well as homodimers [23]. The nuclear-localized homodimerization of OsPHR2 protein was also reported $[7,24]$. All these findings suggest that PHR-like TFs can act redundantly and form an integrated system in Pi-starvation signaling in plants.

\section{The Multifunctional Role of PHR1}

The main idea of this review is to point out recent findings around PHR protein family members except their self-evident DNA-binding role. However, it is worth to mention that PHR transcription factors target broad range of genes that are not connected directly with the Pi signaling. Here, we would like to present relevant studies concerning PHR1 role in various biological processes in plants.

\subsection{PHR1 Affects Plant Immune System}

$\mathrm{P}$ deficiency makes plants more sensitive and susceptible to become a host of various phytopathogens $[25,26]$. Thus, the plant immunity system has to react immediately to overcome the severe environmental stimuli through changing the composition of hormones and root exudates. PHR1 TF as a major regulator of PSI genes also affects the expression of genes involved in antimicrobial resistance. Antagonistic interactions between three plant hormones: (i) salicylic acid (SA), (ii) jasmonic acid (JA), and (iii) ethylene (ET) trigger resistance against pathogens and herbivory [27,28]. JA induction shares some typical traits observed in Pi-starved plants, such as: anthocyanin accumulation or growth reduction [29], suggesting that both signaling pathways may be connected [30].

The comprehensive data about the contribution of PHR1 to the transcriptional regulation of plant immunity-related (PIR) genes has been published in last few years. In 2016, Khan et al. showed the significant increase of JA level in Arabidopsis leaves and roots under low-Pi treatment [31]. Additionally, the molecular analysis of loss-of-function phr1-1 mutant revealed that this induction may be partially controlled by the PHR1 TF. The activation of JA signaling pathway upon Pi deficiency was delayed in the phr1-1 mutant, but not abolished completely, indicating the presence of other transcription factors that may regulate this process [31]. One year later, global ChIP-seq (chromatin immuno-precipitation-sequencing) experiment published by Castrillo et al. uncovered the significant enrichment in clusters of JA- and SA-related genes involved in plant defense, targeted by PHR1 in Arabidopsis [32]. In phr1 and phr1 phl1 mutants most of the SA-responsive genes were upregulated compared to wild type. Where for majority of JA-responsive genes their expression was lower in Arabidopsis mutants than in wild type. Further, they found that phr1 phl1 double mutants exhibit enhanced activation of plant immunity, suggesting the repressing role of AtPHR1/AtPHL1 TFs on plant immune system [32]. These results are consist with related reports showing, (i) that transcription of ET biosynthesis genes may be affected by AtPHR1 activity [11] and (ii) a group of candidate genes involved in SA, JA, and ET signal transduction were differentially expressed upon Pi deficiency in sorghum [33].

Moreover, PHR1-dependent phosphate starvation responses (PSR) may be altered by root microbial communities in Arabidopsis. It was shown that intact PSR suppress the root colonization by fungal root endophytes [34], where synthetic bacterial community (SynCom) triggers PHR1 activity in low-Pi conditions [32].

\subsection{Metal-Phosphate Relationship Modulated by PHR1}

In soils, metal cations (i.e., $\mathrm{Ca}^{2+}, \mathrm{Zn}^{2+}, \mathrm{Fe}^{3+}$ ) form insoluble precipitates with the inorganic forms of phosphate impeding the availability of these elements for plants [35-37]. While in plant cells, metal homeostasis involves interactions with enzymes and organic macromolecules as well as negatively charged Pi altering its activity. Extracellular Pi level also can affect the concentration of metal ions acquired by plant root system. For example, the expression of gene encoding highly conserved ferretin 1 (FER1) iron-binding protein is strongly induced upon Pi scarcity [38]. Bournier et al. found that Arabidopsis phr1 phl1 loss-of-function mutant accumulates iron upon Pi deficiency [39]. Interestingly, 
the low-Pi induced expression of AtFER1 gene was completely lost and different cellular patterns of iron distribution were observed. They showed that both PHR1 and PHL1 proteins directly bind to the P1BS motif within the promoter of AtFER1 gene inducing its transcription under Pi deficiency, in a Pi-specific manner [39]. Cross-talk between Pi and zinc signaling has been also recognized in the PHR1-dependent manner. Usually, P and Zn elements are present in a small amount in the soils and are barely available for plants. The transcription of two genes encoding zinc transporters (ZIP2 and ZIP4) is positively regulated by PHR1 TF [40]. Besides, comparative analysis of the collections of transcriptomic data highlighted the PHR1-dependent induction of candidate genes involved in calcium signaling in Pi-depleted roots as well [41].

\subsection{Double-Faced Role of PHR1 in the Regulation of Sulfate Homeostasis}

In addition, few reports also describe the involvement of PHR1 TF into the transcription of non-metal ions homeostasis. Rouached et al. showed the involvement of PHR1 TF into the sulfate transfer from shoot to root during Pi starvation [16]. They found the presence of P1BS motifs within two genes (SULTR1;3 and SULTR2;1) encoding sulfate transporters. Further, molecular analysis of phr1 mutant revealed that PHR1 TF plays both a positive and negative role on the expression of genes encoding sulfate transporters. They observed the induction of the SULTR1;3 gene expression upon low-Pi, but repression of the SULTR2;1 and SULTR3;4 (not P1BS holder) genes expression in Arabidopsis [16,42].

\section{Transcriptional Regulation of PHR1 Gene Expression}

Broadly, signaling pathways recruit TFs, which function as a last executor in the stepwise action leading to precise changes in target gene expression. However, long distance or systemic sensing pathways trigger each other and recruit a wide range of TFs to coordinately manage the steady state of living cells. In Arabidopsis and barley, PHR1 gene expression is not particularly Pi responsive and its transcript level was not seen to change in different Pi regimes $[6,43]$.

\section{PHR1 Promoter as a Station for Many Plant TFs}

Recently, several TFs that regulate AtPHR1 gene expression in various conditions have been uncovered. In 2017, Liu et al. identified a few cis-regulatory elements within the AtPHR1 promoter, including two elongated hypocotyl 5 (HY5 TF) binding sites (ACGT-containing elements (ACEs) [44]), one far-red elongated hypocotyl 3 (FHY3 TF), and far-red-impaired response 1 (FAR1 TF) binding site (FBS; CACGCGC [45]), and a palindromic repeat sequence similar to the ethylene-insensitive 3 (EIN3 TF) binding site (EBS) [46]) [47]. They observed that AtPHR1 gene expression is induced by light. Additionally, AtPHR1 transcript levels were positively correlated with the intensity of light, and the expression levels of eight PSI target genes, activated by PHR1, were significantly lower in dark-grown plants compared with light-grown (Figure 1). Extensive work by Liu's group proved that FHY3 and FAR1 TFs positively regulate and HY5 TF negatively regulates AtPHR1 expression and PSI genes [47]. What is more, another analysis showed that the transcript levels of AtPHR1 and the PSI genes were enhanced by 1-aminocyclopropane-1-carboxylate (ACC; the immediate precursor of ethylene) treatment and Pi deficiency enhances plant sensitivity to ethylene, as reflected by induction of PSI gene expression $[47,48]$. Such cross-talk is very likely mediated by EIN3 TF, which directly binds to the AtPHR1 5'-UTR and specifically recognize the EBS sequence. The FHY3 and EIN3 TFs form a complex and together coordinately regulate AtPHR1 expression in response to both light and ethylene stimulus [47]. Recently, many groups have shown that low-Pi induced responses integrate ethylene signaling into the molecular network, which helps to remodel the root architecture and increase Pi mining capability [47,49-51]. Later, Huang et al. identified three auxin-response elements: one copy of the AuxRE (GAGACA) in 5'-UTR and two copies of the TGA (AACGAC) elements in the promoter (Figure 1). They found also that two auxin response factors, ARF7 and ARF19, bind to these DNA motifs within AtPHR1 5'-UTR and promoter sequences to positively regulate its gene expression. Further, 
the ARF7/ARF19 expression patterns in roots are similar to that of AtPHR1 gene [52]. Interestingly, Huang's group found auxin-response elements in the promoters of most MYB-CC family genes in Arabidopsis, which were confirmed to exhibit functional redundancy to AtPHR1 protein $[18,19,52]$. They proposed a model in which plants exposed to Pi scarcity showed increased sensitivity of an auxin receptor, transport inhibitor response 1 (TIR1), which led to upregulation of ARF7/ARF19 TFs following the induction of AtPHR1 expression and their PSI target genes in roots [52]. Year by year we get clues suggesting that in order to understand the role of PHR-like TFs in maintaining phosphate homeostasis, we need to look extensively at every single step of the signal transduction pathway.

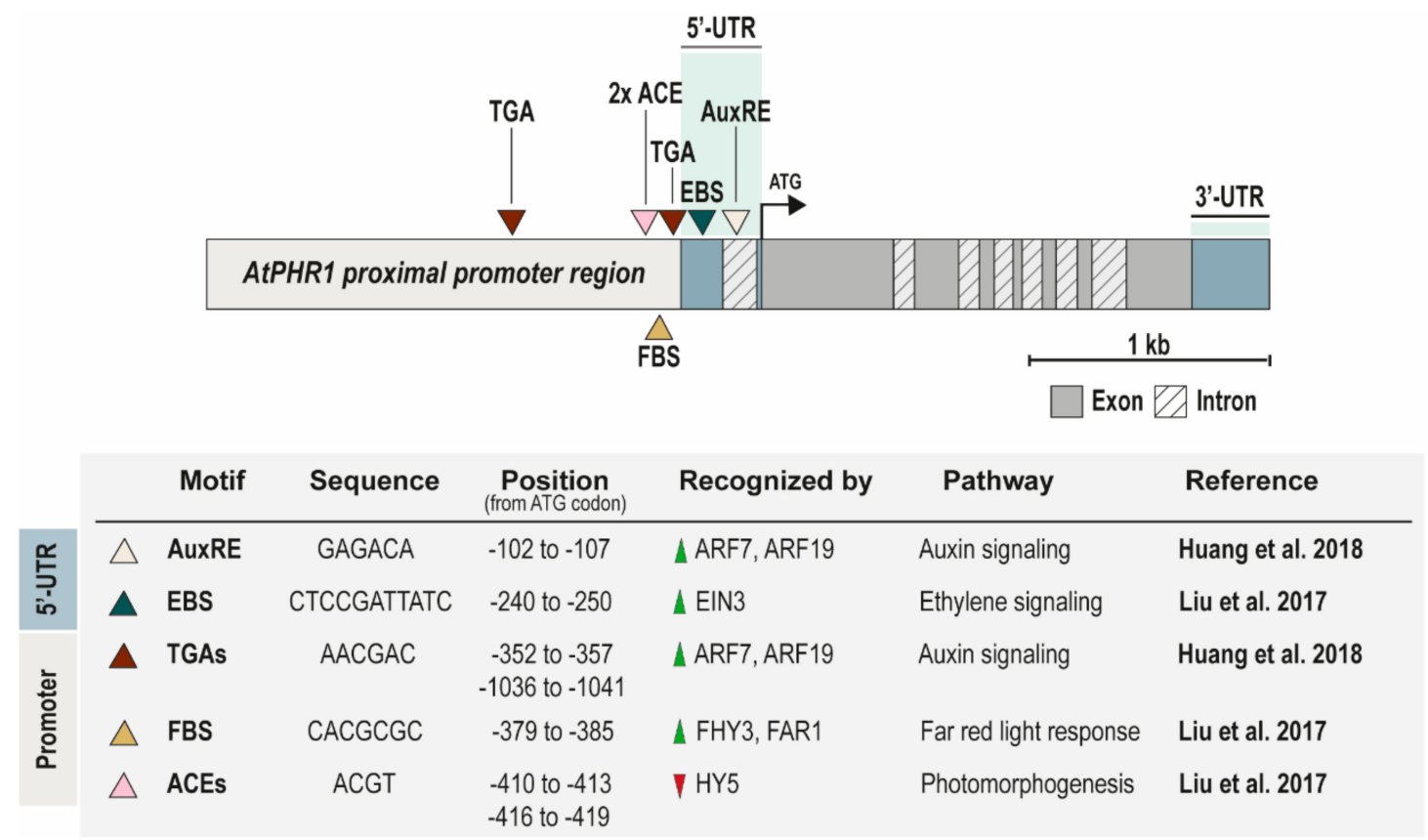

Figure 1. Arabidopsis PHR1 gene structure with outlined major cis-regulatory motifs. Summary table provides detailed information about all relevant motifs published recently. Green and red triangles in column: "recognized by", depict up- and down-regulation of PHR1 genes expression by particular transcription factors (TFs), respectively.

\section{PHR1 Post-Translational Modifications}

Post-translational modification (PTM) is a biochemical modification that occurs to one or more amino acids on a translated protein. Such modification is mostly catalyzed by enzymes that recognize specific target sequences, and may determine the secondary structure of the target proteins and their subcellular localization, activity, and stability [53]. One of the most common and evolutionarily conserved PTMs in eukaryotic cells is mono- or poly-SUMOylation, which involves the binding of small ubiquitin-related modifier (SUMO) protein. The SUMO protein, with an average $10 \mathrm{kDa}$ molecular mass, leads to increased target protein mass or spatial surface related to protein-protein and protein-DNA interactions [54]. Previous work established that PHR-like TFs are SUMOylated via SIZ1 (SAP and MIZ/SP-RING zinc finger domain-containing protein 1) SUMO E3 ligase in Arabidopsis [55], rice [56], and Malus domestica (Borkh.) [57]. The pioneering work of Miura's group confirmed that AtSIZ1 is a single-gene family that encodes protein localized to nuclear speckles in Arabidopsis cells. The siz1 loss-of-function mutant exhibits symptoms that are associated with Pi deficiency, such as reduced primary root growth and increased lateral root and root hair length and density, higher root/shoot mass ratio, anthocyanin accumulation, and upregulation of PSI gene expression [55]. There are two lysine residues within the AtPHR1 amino acid sequence, in positions 261 and 372, that are crucial for SUMO binding, and it was proved that K261R and K372R mutations prevent SUMOylation of PHR1 [55]. 
The expression level of AtPHR1 gene is relatively stable during Pi deficiency. So far, many groups have suggested that AtSIZ1-conducted SUMOylation stabilizes the level and activity of AtPHR1 protein and accelerates its binding affinity to the P1BS motifs present in the regulatory regions of PSI target genes, such as AtIPS1 (INDUCED BY PHOSPHATE STARVATION 1) and AtRNS1 (RIBONUCLEASE 1) [55-57]. However, mutation of OsSIZ1 gene revealed a dual role of SIZ1 E3 ligase in the regulation of Pi homeostasis in rice. Among 13 high-affinity Pi transporters (PHT1 protein family) in rice, OsPT1 and OsPT8 gene expression was induced in siz1 rice mutants under Pi deficiency. On the contrary, suppression of PSI genes such as OsPT2 and OsPT6 was also observed in this study [56]. Thus, AtSIZ1 and OsSIZ1 can act negatively or positively on the expression of PSI genes, even on genes that are not targeted by PHR1 transcription factors. Because of the lack of data, we can only speculate that various SIZ1-SUMOylated transcription factors work together in response to diverse environmental stresses in plants [55,58-62]. So far, there are no data on other PTMs that may affect PHR1 activity.

\section{PHR1 Meets Nitrogen and Phosphate Sensors}

The concentration of nutrients in the plant tissues is determined by nutrient-specific overlapping pathways that cooperate to balance nitrogen $(\mathrm{N})$ and $\mathrm{P}$ uptake [63-65]. Fertilizers with additive $\mathrm{N}$ macroelement can increase the plants' $\mathrm{P}$ uptake and the proper N:P supply ratio, making it essential for promoting plant growth and subsequent high crop yields [66,67]. Variations in nutrient availability can alter specific gene expression levels or even activate the expression of genes that were inactive before. Related studies on OsPHR3 TF revealed that it is responsive to different forms of $\mathrm{N}$ irrespective of Pi regime. Sun's group raised the hypothesis that OsPHR1/2/3/4 genes can also take part in the cross-talk between $\mathrm{N}$ and P [42]. In this part, we would like to point out major research breakthroughs that were made in last few years and connect PHR-mediated phosphate responses with nitrate signaling (Figure 2).

\subsection{SPX Proteins Navigate PHR1 in Plant Cells}

Another way the Pi-related regulation of PHR1 transcriptional activity exists is through interaction with proteins containing SPX (a name combining suppressor of yeast GPA1 (YG1), CDK inhibitor in yeast $\mathrm{PHO}$ pathway (Pho81), and xenotropic and polytropic retrovirus receptor (XPR1)) domains [8,68-70]. There are four SPX proteins in Arabidopsis, AtSPX1-AtSPX4 [71-73], and six in rice, OsSPX1-OsSPX6 $[8,68,74,75]$. The AtSPX genes are highly homologous, however various expression patterns and subcellular localizations were described for them, indicating their functional diversity [70]. A nuclear protein AtSPX1 sequesters AtPHR1 in a Pi-dependent manner and inhibits its activity in Arabidopsis. In Pi-starved plants, AtSPX1/2/3 proteins are quickly degraded by the $26 \mathrm{~S}$ proteasome pathway and AtPHR1 can freely regulate the expression of PSI genes. While the increasing Pi levels enhance the AtSPX1 protein half-life, they could preferentially interact with AtPHR1 TF, diminishing AtPHR1 binding capability to the P1BS cis-elements. Interestingly, SPX1-SPX3 possess P1BS motifs within their $5^{\prime}$-UTR and/or promoter region and serve as downstream targets of AtPHR1/OsPHR2 proteins. Thus, PHR1 can guide its own central role in Pi sensing by this negative feedback loop $[70,71,76,77]$.

In rice, recent findings proved that contrary to nuclear AtSPX1/OsSPX1 proteins, OsSPX4 localizes in both the cell nucleus and cytoplasm, and it is not Pi-starvation responsive [24]. OsSPX4 physically interacts with OsPHR2 mainly in the cytoplasm, where such action prevents the nucleo-cytoplasmic shutting of OsPHR2 in the presence of Pi. Afterwards, when OsPHR2 is trapped in the cytoplasm, it cannot form homodimers and binds to P1BS motifs, and in consequence the PHR-mediated signal transduction is stopped (Figure 2) [24]. 


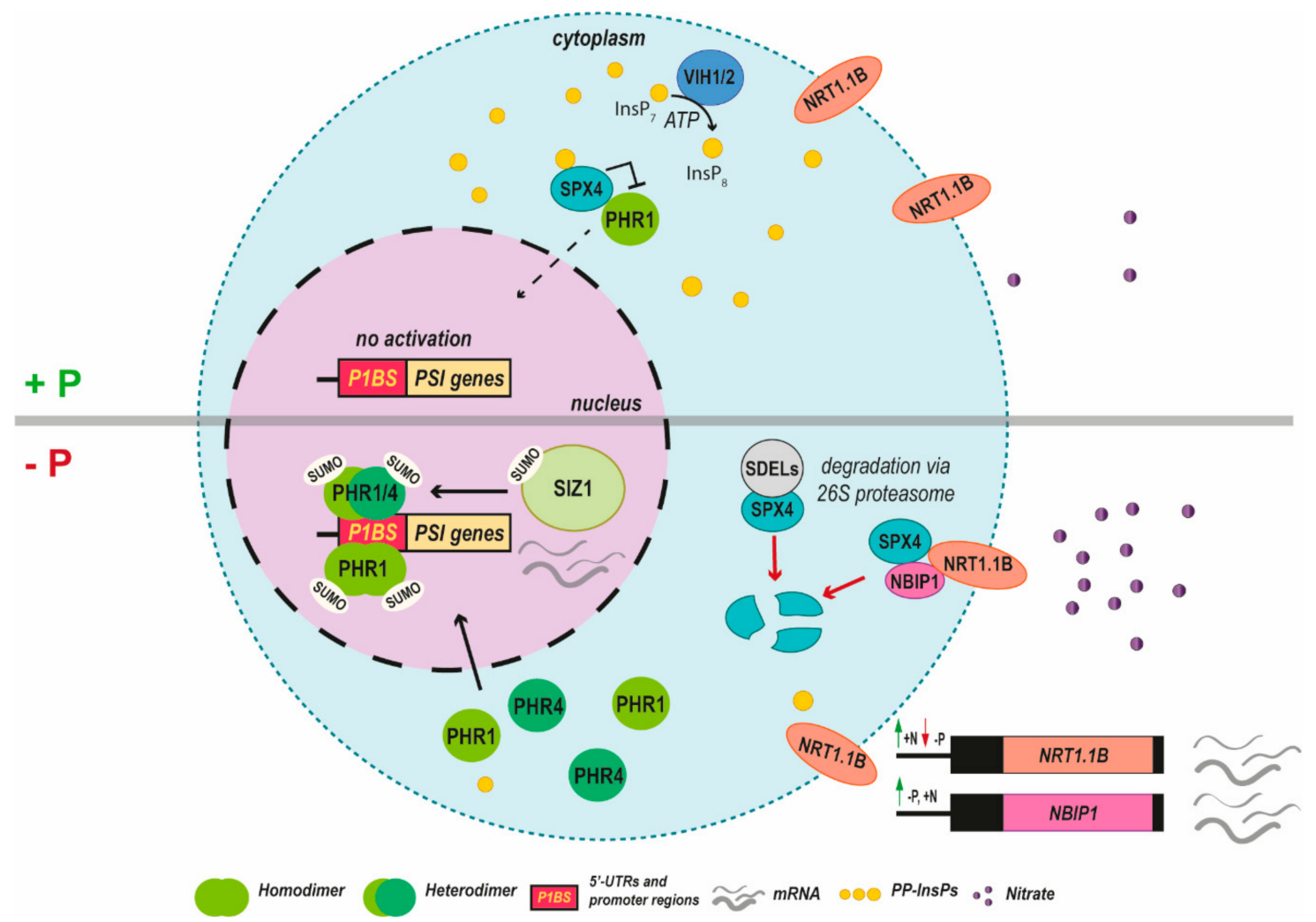

Figure 2. Graphical overview of interplays between PHR-like TFs and other cellular components under Pi scarcity in plant cells updated with current knowledge obtained from extensive research in Arabidopsis and rice. PHR1 TF represents both AtPHR1 and its rice orthologue OsPHR2. Under sufficient phosphate levels $(+\mathrm{P})$, various inositol pyrophosphate isomers (PP-InsPs, depicted as yellow dots of different sizes) are biosynthesized to mimic the cellular Pi status. In the presence of Pi and ATP, $\mathrm{InsP}_{8}$ messenger molecules are generated by the activity of kinase domain within VIH1/2 enzymes. Such PP-InsPs isomers ( $\mathrm{InsP}_{6}, \mathrm{InsP}_{7}, \mathrm{InsP}_{8}$ ) compete to bind to the SPX-domain containing proteins, followed by direct inhibition of AtPHR1/OsPHR2 nucleo-cytoplasmic shuttling. This leads to no activation of PSI genes. When the Pi level turns down, the protein level of specific E3 ligases, such as SPX4 degradation E3 ligases 1 or 2 (SDEL1, SDEL2), increases to target SPX-domain containing proteins for proteasomal degradation pathway. NRT1.1B is transcriptionally induced by high nitrate (N) or repressed by low-Pi, where NBIP1 gene is upregulated by both low-Pi and high-N. The nitrate transporter 1.1B (NRT1.1B) trans-membrane nitrate sensor mediates nitrate-triggered SPX4 degradation with NBIP1 E3 ligase in phosphate signaling upon N sufficient conditions. Upon low-Pi, the PHR-like TFs are more preferentially localized in the nucleus and their structure is stabilized by SUMOylation conducted via SIZ1 activity. The PHR-like TFs, as either homo- or heterodimers, can regulate the transcript level of PSI genes by binding to the P1BS motifs present in the gene $5^{\prime}$-UTR or promoter regions. Green and red arrows indicate up- and down-regulation of gene expression, respectively.

\subsection{Inositol Pyrophosphates (PP-InsPs) as Messenger}

Throughout the paper we have shown many examples of how changes in the Pi level can affect a particular gene's expression and intracellular responses and turn the mode of action in plant development and adaptation to environmental stimuli. It raises the hypothesis that there should be a kind of universal signal element that can sense the signal transduction in response to Pi availability. Among the well-known secondary messengers for a variety of stimuli in eukaryotic cells (also common in plants) are cytosolic calcium ions, $\mathrm{Ca}^{2+}$. In the calcium signal transduction pathway, four $\mathrm{Ca}^{2+}$ ions target and activate calcium-binding messenger protein, calmodulin (CaM), which modulates subsequent protein-protein interactions [78-80]. Calcium ions were mentioned for a reason, because specific inositol 1,4,5-triyphosphates $\left(\mathrm{InsP}_{3}\right)$ bind to the ligand-gated calcium channels and trigger 
the release of stored $\mathrm{Ca}^{2+}$ ions [81,82]. InsP $\mathrm{P}_{3}$ can be further phosphorylated to $\operatorname{Ins} \mathrm{P}_{4}$ [83], Ins $\mathrm{P}_{5}$, $\mathrm{InsP}_{6}$ [84-86], InsP $\mathrm{P}_{7}$ [87], and $\mathrm{InsP}_{8}$ [88].

According to related research reports, especially the inositol pyrophosphates on the highest level of phosphorylation (PP-InsPs) play an important role coordinating cellular Pi homeostasis in plants $[82,86-88]$. Dong et al. showed that $\mathrm{InsP}_{8}$ directly binds to the SPX domain and regulates the interaction between SPX1 and PHR1 in Arabidopsis. They demonstrated that in mutant plants exhibiting no ability to biosynthesize InsP $\mathrm{P}_{8}$, the SPX1-PHR1 complex could not be formed, which resulted in the constitutive activation of PSI genes and overaccumulation of Pi [88]. Recently, biochemical studies have revealed various binding affinities between $\mathrm{InsP}_{6}$ and $\mathrm{InsP}_{7}$ to the SPX domain and competition of PP-InsP isomers prevailing over the physiological concentration of Pi. The elaborated crystal structure of SPX domain exposed some features of binding surface targeted by PP-InsPs. InsP ${ }_{6}$ interacts with the SPX domain via variable hydrogen bond interactions, which may sense different PP-InsP isomers [87]. As far as PHR1 gene expression is not regulated by Pi status, its activity can be fine-tuned by the presence of specific SPX-InsP complexes in an intracellular Pi-dependent manner.

The bioenergetics and signaling roles of PP-InsP molecules are evolutionarily more ancient than Ins: $\mathrm{P}_{3}$-mediated $\mathrm{Ca}^{2+}$ mobilization [89]. Plants exposed to low-Pi stress reprogram their metabolic pathways to compensate for cellular energetic crisis through the coordination of 5-InsP $\mathrm{P}_{7}$ or InsP $\mathrm{P}_{8}$ levels. In 2019, Zhu et al. reported that two genes encoding inositol pyrophosphate kinases/phosphatases VIP homolog 1/2 (VIH1/2) were able to either generate or break down PP-InsPs in Arabidopsis [90]. The VIH1/2 enzymes are bifunctional, harboring an N-terminal InsP kinase and a C-terminal phosphatase domain [91]. The point mutation within the active site of the kinase domain leads to overaccumulation of Pi and constitutive Pi starvation responses. Further phosphorylated PP-InsP isomers cannot be catalyzed, and they do not mediate SPX4-PHR1/PHL1 arrest. Deletion of either PHR1 or PHL1 can partially rescue the VIH1-2 VIH2-4 double-mutant phenotype, suggesting that both enzymes redundantly regulate Pi homeostasis and their PP-InsP reaction products are part of the PHR1/PHL1 signaling cascade. The dual roles of VIH1/2 may be shaped by cellular concentration of ATP and $\mathrm{Pi}$ [90]. For example, plants growing in soil with sufficient Pi availability are energetically stable, and their increasing cellular level of ATP stimulates PP-InsP kinase activity. Thus, $\mathrm{InsP}_{8}$ isomers are more abundant and act as messengers that transmit information about Pi availability throughout the plant, so PSI responses stay inactive.

Plant hormones may interplay with Pi signaling also through interactions with different InsP isomers. Recent discoveries have shown the possibility of binding either $\mathrm{InsP}_{5}$ to the JA receptors [92] or $\mathrm{InsP}_{6}$ to the auxin receptors [93]. Furthermore, herbivore-induced JA synthesis triggers VIH2-dependent increase in InsP ${ }_{8}$, which can be integrated into JA receptor complex [94].

\subsection{SPX Proteins from the Nitrogen Perspective}

Recently, two breakthrough studies appeared that extended the SPX4-PHR2 module for novel molecules that were known as nitrate sensors. Maeda's and Hu's groups revealed the mechanism by which nitrate activates both Pi and N signaling pathways in plants [75,95]. Maeda et al. found three copies of P1BS cis-regulatory elements in the nitrate-inducible GARP-type transcriptional repressor 1.1 (AtNIGT1.1) promoter, which encodes nuclear localized TF transcriptionally regulated by nitrate. Further investigation of the SPX-PHR1-NIGT1 cascade revealed their role in the modulation of nitrate uptake in a P-dependent manner. Additionally, they proved that the transmembrane protein and nitrate sensor, the nitrate transporter 1.1B (NRT1.1B), recruits SPX4 protein to facilitate its ubiquitination and degradation mediated by NRT1.1B interacting protein 1 (NBIP1) E3 ligase in the presence of $\mathrm{N}$ in rice (Figure 2) [75]. In Arabidopsis, NRT1.1 activity is positively and indirectly regulated by the phosphate 2 (PHO2) ubiquitin-conjugating (UBC) E2 enzyme [96,97]. In a short period of time, two more SPX4 degradation E3 ligases (SDEL1 and SDEL2) were discovered. Both SDEL genes are post-transcriptionally induced by Pi starvation, and their E3 ligase activity directs for degradation SPX4 proteins via ubiquitination of K213 and K299 lysine residues (Figure 2) [69]. Again, it was proved 
that PHR-like TF functions as a master regulator to maintain nutrient homeostasis in plants. The AtPHR1/OsPHR2 TFs could compete with various E3 ligases by interacting with SPX4-PP-InsP-activated protein in either a P- or N-dependent manner, which secures SPX4 from being directed to the $26 \mathrm{~S}$ proteasomal degradation pathway $[69,75]$. The plant demand for $P$ strengthens through developmental stages in which large macromolecules, nucleic acids, and proteins are created from smaller components extensively. Inhibition of $\mathrm{N}$ uptake can lower the plant's demand for $\mathrm{P}$ and cooperatively reduce the negative impact of abiotic stresses.

\section{Conclusions}

Thus far, the given findings indicate that PHR1 transcription factor is a crucial component of Pi signaling in plants. Here, we emphasize the role of cooperation between signaling and hormonal pathways that are most affected by Pi-starved plants. Alterations by addition or deletion of any factor(s) from a signal transduction cascade can result in sudden cellular and molecular changes. We reviewed several breakthrough studies that should be considered during further investigation of the mechanistic picture determining plant tolerance to phosphate scarcity from the perspective of the PHR protein family. The first described PHR protein family member, PHR1 in Arabidopsis, redundantly cooperates with other homologous proteins (i.e., AtPHR2, AtPHL1, AtPHL2), which may equally contribute to the signaling pathway. It is believed that specific dimer sets consisting of PHR-like TFs may regulate the expression of essential genes, overcoming the negative impact of low-Pi stress.

The "phosphate problem" has recently gained much attention due to the anthropogenic impact on the environment and limited phosphorus supply. Crop improvement in current plant breeding will occur due to revealing the mechanism of Pi tolerance. Such knowledge may be used to engineer crop cultivars with improved ability to acquire and utilize Pi. In the near future, efforts should be put into investigating the relationship between different PP-InsP isomers that may coordinate cellular phosphate balance with metabolic messengers. These evolutionarily conserved signaling molecules speak directly on behalf of plants, and decoding this language may be invaluable.

Author Contributions: Conceptualization, writing—original draft preparation, editing, designing figures: P.S.; supervision and writing-review and editing: A.P.

Funding: This work was funded by the National Science Centre, Poland, grant numbers DEC-2013/11/B/NZ9/01761, UMO-2016/23/B/NZ9/00857, and UMO-2015/19/N/NZ9/00218, and by KNOW RNA Research Centre in Poznan, grant number 01/KNOW2/2014.

Conflicts of Interest: The authors declare no conflict of interest.

\section{References}

1. Vance, C.P.; Uhde-Stone, C.; Allan, D.L. Phosphorus acquisition and use: Critical adaptations by plants for securing a nonrenewable resource. New Phytol. 2003, 157, 423-447. [CrossRef]

2. Heffer, P.; Prud'homme, M. Nutrients as limited resources: Global trends in fertilizer production and use. In Improving Water and Nutrient-Use Efficiency in Food Production Systems; John Wiley \& Sons, Inc.: Hoboken, NJ, USA, 2013; pp. 57-78, ISBN 9780813819891.

3. Shimogawara, K.; Wykoff, D.D.; Usuda, H.; Grossman, A.R. Chlamydomonas reinhardtii mutants abnormal in their responses to phosphorus deprivation. Plant Physiol. 1999, 120, 685-694. [CrossRef] [PubMed]

4. Wykoff, D.D.; Grossman, A.R.; Weeks, D.P.; Usuda, H.; Shimogawara, K. Psr1, a nuclear localized protein that regulates phosphorus metabolism in Chlamydomonas. Proc. Natl. Acad. Sci. USA 1999, 96, 15336-15341. [CrossRef] [PubMed]

5. Bajhaiya, A.K.; Dean, A.P.; Zeef, L.A.; Webster, R.E.; Pittman, J.K. PSR1 is a global transcriptional regulator of phosphorus deficiency responses and carbon storage metabolism in Chlamydomonas reinhardtii. Plant Physiol. 2016, 170, 1216-1234. [CrossRef] [PubMed]

6. Rubio, V.; Linhares, F.; Solano, R.; Martín, A.C.; Iglesias, J.; Leyva, A.; Paz-ares, J. A conserved MYB transcription factor involved in Phosphate starvation signaling both in vascular plants and in unicellular algae. Genes Dev. 2001, 15, 2122-2133. [CrossRef] [PubMed] 
7. Zhou, J.; Jiao, F.; Wu, Z.; Li, Y.; Wang, X.; He, X.; Zhong, W.; Wu, P. OsPHR2 is involved in Phosphate-starvation signaling and excessive Phosphate accumulation in shoots of plants. Plant Physiol. 2008, 146, 1673-1686. [CrossRef]

8. Liu, F.; Wang, Z.; Ren, H.; Shen, C.; Li, Y.; Ling, H.Q.; Wu, C.; Lian, X.; Wu, P. OsSPX1 suppresses the function of OsPHR2 in the regulation of expression of OsPT2 and Phosphate homeostasis in shoots of rice. Plant J. 2010, 62, 508-517. [CrossRef]

9. Nilsson, L.; Müller, R.; Nielsen, T.H. Increased expression of the MYB-related transcription factor, PHR1, leads to enhanced Phosphate uptake in Arabidopsis thaliana. Plant. Cell Environ. 2007, 30, 1499-1512. [CrossRef]

10. Pant, B.D.; Burgos, A.; Pant, P.; Cuadros-Inostroza, A.; Willmitzer, L.; Scheible, W.R. The transcription factor PHR1 regulates lipid remodeling and triacylglycerol accumulation in Arabidopsis thaliana during phosphorus starvation. J. Exp. Bot. 2015, 66, 1907-1918. [CrossRef]

11. Bustos, R.; Castrillo, G.; Linhares, F.; Puga, M.I.; Rubio, V.; Pérez-Pérez, J.; Solano, R.; Leyva, A.; Paz-Ares, J. A central regulatory system largely controls transcriptional activation and repression responses to Phosphate starvation in Arabidopsis. PLoS Genet. 2010, 6, e1001102. [CrossRef]

12. Wu, W.S.; Lai, F.J. Functional redundancy of transcription factors explains why most binding targets of a transcription factor are not affected when the transcription factor is knocked out. BMC Syst. Biol. 2015, 9, S2. [CrossRef] [PubMed]

13. Kuntz, S.G.; Williams, B.A.; Sternberg, P.W.; Wold, B.J. Transcription factor redundancy and tissue-specific regulation: Evidence from functional and physical network connectivity. Genome Res. 2012, 22, 1907-1919. [CrossRef] [PubMed]

14. Jiang, M.; Sun, L.; Isupov, M.N.; Littlechild, J.A.; Wu, X.; Wang, Q.; Wang, Q.; Yang, W.; Wu, Y. Structural basis for the target DNA recognition and binding by the MYB domain of Phosphate starvation response 1. FEBS J. 2019, 286, 2809-2821. [CrossRef] [PubMed]

15. Sobkowiak, L.; Bielewicz, D.; Malecka, E.M.; Jakobsen, I.; Albrechtsen, M.; Szweykowska-Kulinska, Z.; Pacak, A. The Role of the P1BS element containing promoter-driven genes in Pi transport and homeostasis in plants. Front. Plant Sci. 2012, 3, 1-5. [CrossRef]

16. Rouached, H.; Secco, D.; Arpat, B.; Poirier, Y. The transcription factor PHR1 plays a key role in the regulation of sulfate shoot-to-root flux upon Phosphate starvation in Arabidopsis. BMC Plant Biol. 2011, 11, 19. [CrossRef]

17. Sega, P.; Kruszka, K.; Szewc, Ł.; Szweykowska-Kulińska, Z.; Pacak, A. Identification of transcription factors that bind to the 5'-UTR of the barley PHO2 gene. Plant Mol. Biol. 2019, 1-16. [CrossRef]

18. Sun, L.; Song, L.; Zhang, Y.; Zheng, Z.; Liu, D. Arabidopsis PHL2 and PHR1 act redundantly as the key components of the central regulatory system controlling transcriptional responses to Phosphate starvation. Plant Physiol. 2016, 170, 499-514. [CrossRef]

19. Wang, Z.; Zheng, Z.; Song, L.; Liu, D. Functional characterization of Arabidopsis PHL4 in Plant response to Phosphate starvation. Front. Plant Sci. 2018, 9, 1432. [CrossRef]

20. Wang, J.; Sun, J.; Miao, J.; Guo, J.; Shi, Z.; He, M.; Chen, Y.; Zhao, X.; Li, B.; Han, F.; et al. A Phosphate starvation response regulator Ta-PHR1 is involved in Phosphate signalling and increases grain yield in wheat. Ann. Bot. 2013, 111, 1139-1153. [CrossRef]

21. Ren, F.; Guo, Q.Q.; Chang, L.L.; Chen, L.; Zhao, C.Z.; Zhong, H.; Li, X.B. Brassica napus PHR1 gene encoding a MYB-like protein functions in response to Phosphate starvation. PLoS ONE 2012, 7, e44005. [CrossRef]

22. Guo, M.; Ruan, W.; Li, C.; Huang, F.; Zeng, M.; Liu, Y.; Yu, Y.; Ding, X.; Wu, Y.; Wu, Z.; et al. Integrative comparison of the role of the PHOSPHATE RESPONSE1 subfamily in Phosphate signaling and homeostasis in rice. Plant Physiol. 2015, 168, 1762-1776. [CrossRef] [PubMed]

23. Ruan, W.; Guo, M.; Wu, P.; Yi, K. Phosphate starvation induced OsPHR4 mediates Pi-signaling and homeostasis in rice. Plant Mol. Biol. 2017, 93, 327-340. [CrossRef] [PubMed]

24. Lv, Q.; Zhong, Y.; Wang, Y.; Wang, Z.; Zhang, L.; Shi, J.; Wu, Z.; Liu, Y.; Mao, C.; Yi, K.; et al. SPX4 negatively regulates Phosphate signaling and homeostasis through its interaction with PHR2 in rice. Plant Cell 2014, 26, 1586-1597. [CrossRef] [PubMed]

25. McDonald, A.E.; Grant, B.R.; Plaxton, W.C. Phosphite (phosphorous acid): Its relevance in the environment and agriculture and influence on plant Phosphate starvation response. J. Plant Nutr. 2001, 24, 1505-1519. [CrossRef] 
26. Decker, E.L.; Alder, A.; Hunn, S.; Ferguson, J.; Lehtonen, M.T.; Scheler, B.; Kerres, K.L.; Wiedemann, G.; Safavi-Rizi, V.; Nordzieke, S.; et al. Strigolactone biosynthesis is evolutionarily conserved, regulated by Phosphate starvation and contributes to resistance against phytopathogenic fungi in a moss, Physcomitrella patens. New Phytol. 2017, 216, 455-468. [CrossRef]

27. Robert-Seilaniantz, A.; Grant, M.; Jones, J.D. Hormone crosstalk in plant disease and defense: More than just jasmonate-salicylate antagonism. Annu. Rev. Phytopathol. 2011, 49, 317-343. [CrossRef]

28. Yang, Y.X.; Ahammed, G.J.; Wu, C.; Fan, S.Y.; Zhou, Y.H. Crosstalk among Jasmonate, Salicylate and Ethylene signaling pathways in plant disease and immune responses. Curr. Protein Pept. Sci. 2015, 16, 450-461. [CrossRef]

29. Li, T.; Jia, K.P.; Lian, H.L.; Yang, X.; Li, L.; Yang, H.Q. Jasmonic acid enhancement of anthocyanin accumulation is dependent on phytochrome A signaling pathway under far-red light in Arabidopsis. Biochem. Biophys. Res. Commun. 2014, 454, 78-83. [CrossRef]

30. Crombez, H.; Motte, H.; Beeckman, T. Tackling plant Phosphate starvation by the roots. Dev. Cell 2019, 48, 599-615. [CrossRef]

31. Khan, G.A.; Vogiatzaki, E.; Glauser, G.; Poirier, Y. Phosphate deficiency induces the Jasmonate pathway and enhances resistance to insect herbivory. Plant Physiol. 2016, 171, 632-644. [CrossRef]

32. Castrillo, G.; Teixeira, P.J.; Paredes, S.H.; Law, T.F.; de Lorenzo, L.; Feltcher, M.E.; Finkel, O.M.; Breakfield, N.W.; Mieczkowski, P.; Jones, C.D.; et al. Root microbiota drive direct integration of Phosphate stress and immunity. Nature 2017, 543, 513-518. [CrossRef] [PubMed]

33. Zhang, J.; Jiang, F.; Shen, Y.; Zhan, Q.; Bai, B.; Chen, W.; Chi, Y. Transcriptome analysis reveals candidate genes related to phosphorus starvation tolerance in sorghum. BMC Plant Biol. 2019, 19, 306. [CrossRef] [PubMed]

34. Hiruma, K.; Gerlach, N.; Sacristán, S.; Nakano, R.T.; Hacquard, S.; Kracher, B.; Neumann, U.; Ramírez, D.; Bucher, M.; O'Connell, R.J.; et al. Root endophyte Colletotrichum tofieldiae confers plant fitness benefits that are Phosphate status dependent. Cell 2016, 165, 464-474. [CrossRef] [PubMed]

35. Gupta, D.K.; Chatterjee, S.; Datta, S.; Veer, V.; Walther, C. Role of Phosphate fertilizers in heavy metal uptake and detoxification of toxic metals. Chemosphere 2014, 108, 134-144. [CrossRef] [PubMed]

36. Briat, J.F.; Rouached, H.; Tissot, N.; Gaymard, F.; Dubos, C. Integration of P, S, Fe, and Zn nutrition signals in Arabidopsis thaliana: Potential involvement of PHOSPHATE STARVATION RESPONSE 1 (PHR1). Front. Plant Sci. 2015, 6, 290. [CrossRef] [PubMed]

37. Mathan, K.K.; Amberger, A. Influence of iron on the uptake of phosphorus by maize. Plant Soil 1977, 46, 413-422. [CrossRef]

38. Hirsch, J.; Marin, E.; Floriani, M.; Chiarenza, S.; Richaud, P.; Nussaume, L.; Thibaud, M.C. Phosphate deficiency promotes modification of iron distribution in Arabidopsis plants. Biochimie 2006, 88, 1767-1771. [CrossRef]

39. Bournier, M.; Tissot, N.; Mari, S.; Boucherez, J.; Lacombe, E.; Briat, J.F.; Gaymard, F. Arabidopsis ferritin 1 (AtFer1) gene regulation by the Phosphate starvation response 1 (AtPHR1) transcription factor reveals a direct molecular link between iron and Phosphate homeostasis. J. Biol. Chem. 2013, 288, 22670-22680. [CrossRef]

40. Xie, X.; Hu, W.; Fan, X.; Chen, H.; Tang, M. Interactions between phosphorus, Zinc, and iron homeostasis in nonmycorrhizal and mycorrhizal plants. Front. Plant Sci. 2019, 10, 1172. [CrossRef]

41. Linn, J.; Ren, M.; Berkowitz, O.; Ding, W.; van der Merwe, M.J.; Whelan, J.; Jost, R. Root cell-specific regulators of Phosphate-dependent growth. Plant Physiol. 2017, 174, 1969-1989. [CrossRef]

42. Sun, Y.; Luo, W.; Jain, A.; Liu, L.; Ai, H.; Liu, X.; Feng, B.; Zhang, L.; Zhang, Z.; Guohua, X.; et al. OsPHR3 affects the traits governing nitrogen homeostasis in rice. BMC Plant Biol. 2018, 18, 241. [CrossRef] [PubMed]

43. Pacak, A.; Barciszewska-Pacak, M.; Świda-Barteczka, A.; Kruszka, K.; Sega, P.; Milanowska, K.; Jakobsen, I.; Jarmołowski, A.; Szweykowska-Kulińska, Z. Heat stress affects pi-related genes expression and inorganic Phosphate deposition/accumulation in Barley. Front. Plant Sci. 2016, 7, 926. [CrossRef] [PubMed]

44. Osterlund, M.T.; Hardtke, C.S.; Wei, N.; Deng, X.W. Targeted destabilization of HY5 during light-regulated development of Arabidopsis. Nature 2000, 405, 462-466. [CrossRef] [PubMed]

45. Lin, R.; Ding, L.; Casola, C.; Ripoll, D.R.; Feschotte, C.; Wang, H. Transposase-derived transcription factors regulate light signaling in Arabidopsis. Science 2007, 318, 1302-1305. [CrossRef] [PubMed] 
46. Solano, R.; Stepanova, A.; Chao, Q.; Ecker, J.R. Nuclear events in ethylene signaling: A transcriptional cascade mediated by ETHYLENE-INSENSITIVE3 and ETHYLENE-RESPONSE-FACTOR1. Genes Dev. 1998, 12, 3703-3714. [CrossRef] [PubMed]

47. Liu, Y.; Xie, Y.; Wang, H.; Ma, X.; Yao, W.; Wang, H. Light and ethylene coordinately regulate the phosphate starvation response through transcriptional regulation of PHOSPHATE STARVATION RESPONSE1. Plant Cell 2017, 29, 2269-2284. [CrossRef]

48. Lei, M.; Zhu, C.; Liu, Y.; Karthikeyan, A.S.; Bressan, R.A.; Raghothama, K.G.; Liu, D. Ethylene signalling is involved in regulation of Phosphate starvation-induced gene expression and production of acid phosphatases and anthocyanin in Arabidopsis. New Phytol. 2011, 189, 1084-1095. [CrossRef]

49. Thibaud, M.C.; Arrighi, J.F.; Bayle, V.; Chiarenza, S.; Creff, A.; Bustos, R.; Paz-Ares, J.; Poirier, Y.; Nussaume, L. Dissection of local and systemic transcriptional responses to Phosphate starvation in Arabidopsis. Plant J. 2010, 64, 775-789. [CrossRef]

50. Neumann, G. The role of ethylene in plant adaptations for Phosphate acquisition in soils-A review. Front. Plant Sci. 2016, 6, 1224. [CrossRef]

51. Nagarajan, V.K.; Smith, A.P. Ethylene's role in Phosphate starvation signaling: More than just a root growth regulator. Plant Cell Physiol. 2012, 53, 277-286. [CrossRef]

52. Huang, K.L.; Ma, G.J.; Zhang, M.L.; Xiong, H.; Wu, H.; Zhao, C.Z.; Liu, C.S.; Jia, H.X.; Chen, L.; Kjorven, J.O.; et al. The ARF7 and ARF19 transcription factors positively regulate PHOSPHATE STARVATION RESPONSE1 in Arabidopsis roots. Plant Physiol. 2018, 178, 413-427. [CrossRef] [PubMed]

53. Mazzucotelli, E.; Mastrangelo, A.M.; Crosatti, C.; Guerra, D.; Stanca, A.M.; Cattivelli, L. Abiotic stress response in plants: When post-transcriptional and post-translational regulations control transcription. Plant Sci. 2008, 174, 420-431. [CrossRef]

54. Praefcke, G.J.; Hofmann, K.; Dohmen, R.J. SUMO playing tag with ubiquitin. Trends Biochem. Sci. 2012, 37, 23-31. [CrossRef] [PubMed]

55. Miura, K.; Rus, A.; Sharkhuu, A.; Yokoi, S.; Karthikeyan, A.S.; Raghothama, K.G.; Baek, D.; Koo, Y.D.; Jin, J.B.; Bressan, R.A.; et al. The Arabidopsis SUMO E3 ligase SIZ1 controls Phosphate deficiency responses. Proc. Natl. Acad. Sci. USA 2005, 102, 7760-7765. [CrossRef]

56. Wang, H.; Sun, R.; Cao, Y.; Pei, W.; Sun, Y.; Zhou, H.; Wu, X.; Zhang, F.; Luo, L.; Shen, Q.; et al. OsSIZ1, a SUMO E3 ligase gene, is involved in the regulation of the responses to Phosphate and nitrogen in rice. Plant Cell Physiol. 2015, 56, 2381-2395. [CrossRef]

57. Zhang, R.F.; Zhou, L.J.; Li, Y.Y.; You, C.X.; Sha, G.L.; Hao, Y.J. Apple SUMO E3 ligase MdSIZ1 is involved in the response to Phosphate deficiency. J. Plant Physiol. 2019, 232, 216-225. [CrossRef]

58. Park, H.C.; Kim, H.; Koo, S.C.; Park, H.J.; Cheong, M.S.; Hong, H.; Baek, D.; Chung, W.S.; Kim, D.H.; Bressan, R.A.; et al. Functional characterization of the SIZ/PIAS-type SUMO E3 ligases, OsSIZ1 and OsSIZ2 in rice. Plant. Cell Environ. 2010, 33, 1923-1934. [CrossRef]

59. Jin, J.B.; Jin, Y.H.; Lee, J.; Miura, K.; Yoo, C.Y.; Kim, W.Y.; Van Oosten, M.; Hyun, Y.; Somers, D.E.; Lee, I.; et al. The SUMO E3 ligase, AtSIZ1, regulates flowering by controlling a salicylic acid-mediated floral promotion pathway and through affects on FLC chromatin structure. Plant J. 2008, 53, 530-540. [CrossRef]

60. Zhou, L.J.; Zhang, C.L.; Zhang, R.F.; Wang, G.L.; Li, Y.Y.; Hao, Y.J. The SUMO E3 ligase MdSIZ1 targets MdbHLH104 to regulate plasma membrane $\mathrm{H}^{+}$-ATPase activity and iron homeostasis. Plant Physiol. 2019, 179, 88-106. [CrossRef]

61. Niu, D.; Lin, X.L.; Kong, X.; Qu, G.P.; Cai, B.; Lee, J.; Jin, J.B. SIZ1-mediated SUMOylation of TPR1 suppresses plant immunity in Arabidopsis. Mol. Plant 2019, 12, 215-228. [CrossRef]

62. Mishra, N.; Srivastava, A.P.; Esmaeili, N.; Hu, W.; Shen, G. Overexpression of the rice gene OsSIZ1 in Arabidopsis improves drought-, heat-, and salt-tolerance simultaneously. PLoS ONE 2018, 13, e0201716. [CrossRef] [PubMed]

63. Park, B.S.; Seo, J.S.; Chua, N.H. NITROGEN LIMITATION ADAPTATION recruits PHOSPHATE2 to target the Phosphate transporter PT2 for degradation during the regulation of Arabidopsis Phosphate homeostasis. Plant Cell 2014, 26, 454-464. [CrossRef] [PubMed]

64. Lin, W.Y.; Huang, T.K.; Chiou, T.J. Nitrogen limitation adaptation, a target of microRNA827, mediates degradation of plasma membrane-localized Phosphate transporters to maintain phosphate homeostasis in Arabidopsis. Plant Cell 2013, 25, 4061-4074. [CrossRef] [PubMed] 
65. Medici, A.; Marshall-Colon, A.; Ronzier, E.; Szponarski, W.; Wang, R.; Gojon, A.; Crawford, N.M.; Ruffel, S.; Coruzzi, G.M.; Krouk, G. AtNIGT1/HRS1 integrates nitrate and Phosphate signals at the Arabidopsis root tip. Nat. Commun. 2015, 6, 6274. [CrossRef] [PubMed]

66. Khan, F.; Khan, S.; Fahad, S.; Faisal, S.; Hussain, S.; Ali, S.; Ali, A. Effect of different levels of nitrogen and phosphorus on the phenology and yield of maize varieties. Am. J. Plant Sci. 2014, 5, 2582-2590. [CrossRef]

67. Luo, X.; Mazer, S.J.; Guo, H.; Zhang, N.; Weiner, J.; Hu, S. Nitrogen: Phosphorous supply ratio and allometry in five alpine plant species. Ecol. Evol. 2016, 6, 8881-8892. [CrossRef] [PubMed]

68. Wang, C.; Ying, S.; Huang, H.; Li, K.; Wu, P.; Shou, H. Involvement of OsSPX1 in phosphate homeostasis in rice. Plant J. 2009, 57, 895-904. [CrossRef]

69. Ruan, W.; Guo, M.; Wang, X.; Guo, Z.; Xu, Z.; Xu, L.; Zhao, H.; Sun, H.; Yan, C.; Yi, K. Two RING-finger ubiquitin E3 ligases regulate the degradation of SPX4, an internal Phosphate sensor, for Phosphate homeostasis and signaling in rice. Mol. Plant 2019, 12, 1060-1074. [CrossRef]

70. Puga, M.I.; Mateos, I.; Charukesi, R.; Wang, Z.; Franco-Zorrilla, J.M.; de Lorenzo, L.; Irigoyen, M.L.; Masiero, S.; Bustos, R.; Rodriguez, J.; et al. SPX1 is a Phosphate-dependent inhibitor of Phosphate starvation response 1 in Arabidopsis. Proc. Natl. Acad. Sci. USA 2014, 111, 14947-14952. [CrossRef]

71. Duan, K.; Yi, K.; Dang, L.; Huang, H.; Wu, W.; Wu, P. Characterization of a sub-family of Arabidopsis genes with the SPX domain reveals their diverse functions in plant tolerance to phosphorus starvation. Plant J. 2008, 54, 965-975. [CrossRef]

72. Li, Y.; Wu, H.; Fan, H.; Zhao, T.; Ling, H.Q. Characterization of the AtSPX3 promoter elucidates its complex regulation in response to phosphorus deficiency. Plant Cell Physiol. 2016, 57, 1767-1778. [CrossRef] [PubMed]

73. Osorio, M.B.; Ng, S.; Berkowitz, O.; De Clercq, I.; Mao, C.; Shou, H.; Whelan, J.; Jost, R. SPX4 acts on PHR1-dependent and -independent regulation of shoot phosphorus status in Arabidopsis. Plant Physiol. 2019, 181, 332-352. [CrossRef] [PubMed]

74. Zhong, Y.; Wang, Y.; Guo, J.; Zhu, X.; Shi, J.; He, Q.; Liu, Y.; Wu, Y.; Zhang, L.; Lv, Q.; et al. Rice SPX6 negatively regulates the Phosphate starvation response through suppression of the transcription factor PHR2. New Phytol. 2018, 219, 135-148. [CrossRef] [PubMed]

75. Hu, B.; Jiang, Z.; Wang, W.; Qiu, Y.; Zhang, Z.; Liu, Y.; Li, A.; Gao, X.; Liu, L.; Qian, Y.; et al. Nitrate-NRT1.1B-SPX4 cascade integrates nitrogen and phosphorus signalling networks in plants. Nat. Plants 2019, 5, 401-413. [CrossRef]

76. Qi, W.; Manfield, I.W.; Muench, S.P.; Baker, A. AtSPX1 affects the AtPHR1-DNA-binding equilibrium by binding monomeric AtPHR1 in solution. Biochem. J. 2017, 474, 3675-3687. [CrossRef]

77. Wang, Z.; Ruan, W.; Shi, J.; Zhang, L.; Xiang, D.; Yang, C.; Li, C.; Wu, Z.; Liu, Y.; Yu, Y.; et al. Rice SPX1 and SPX2 inhibit Phosphate starvation responses through interacting with PHR2 in a Phosphate-dependent manner. Proc. Natl. Acad. Sci. USA 2014, 111, 14953-14958. [CrossRef]

78. Schwartz, A. Role of $\mathrm{Ca}^{2+}$ and EGTA on stomatal movements in Commelina communis L. Plant Physiol. 1985, 79, 1003-1005. [CrossRef]

79. Tai, L.; Li, B.B.; Nie, X.M.; Zhang, P.P.; Hu, C.H.; Zhang, L.; Liu, W.T.; Li, W.Q.; Chen, K.M. Calmodulin is the fundamental regulator of NADK-mediated NAD signaling in plants. Front. Plant Sci. 2019, 10, 681. [CrossRef]

80. Yoo, C.Y.; Mano, N.; Finkler, A.; Weng, H.; Day, I.S.; Reddy, A.S.N.; Poovaiah, B.W.; Fromm, H.; Hasegawa, P.M.; Mickelbart, M.V. A Ca ${ }^{2+} /$ CaM-regulated transcriptional switch modulates stomatal development in response to water deficit. Sci. Rep. 2019, 9, 12282. [CrossRef]

81. Allen, G.J.; Muir, S.R.; Sanders, D. Release of $\mathrm{Ca}^{2+}$ from individual plant vacuoles by both InsP $\mathrm{P}_{3}$ and cyclic ADP-ribose. Science 1995, 268, 735-737. [CrossRef]

82. Shears, S.B.; Ganapathi, S.B.; Gokhale, N.A.; Schenk, T.M.; Wang, H.; Weaver, J.D.; Zaremba, A.; Zhou, Y. Defining signal transduction by inositol Phosphates. Subcell. Biochem. 2012, 59, 389-412. [PubMed]

83. Hermosura, M.C.; Takeuchi, H.; Fleig, A.; Riley, A.M.; Potter, B.V.; Hirata, M.; Penner, R. InsP ${ }_{4}$ facilitates store-operated calcium influx by inhibition of InsP $_{3}$ 5-phosphatase. Nature 2000, 408, 735-740. [CrossRef] [PubMed]

84. Menniti, F.S.; Oliver, K.G.; Putney, J.W.; Shears, S.B. Inositol Phosphates and cell signaling: New views of InsP $_{5}$ and InsP $_{6}$. Trends Biochem. Sci. 1993, 18, 53-56. [CrossRef] 
85. Kuo, H.F.; Chang, T.Y.; Chiang, S.F.; Wang, W.D.; Charng, Y.Y.; Chiou, T.J. Arabidopsis inositol pentakisphosphate 2-kinase, AtIPK1, is required for growth and modulates Phosphate homeostasis at the transcriptional level. Plant J. 2014, 80, 503-515. [CrossRef] [PubMed]

86. Kuo, H.F.; Hsu, Y.Y.; Lin, W.C.; Chen, K.Y.; Munnik, T.; Brearley, C.A.; Chiou, T.J. Arabidopsis inositol Phosphate kinases IPK1 and ITPK1 constitute a metabolic pathway in maintaining Phosphate homeostasis. Plant J. 2018, 95, 613-630. [CrossRef] [PubMed]

87. Wild, R.; Gerasimaite, R.; Jung, J.; Truffault, V.; Pavlovic, I.; Schmidt, A.; Saiardi, A.; Jessen, H.J.; Poirier, Y.; Hothorn, M.; et al. Control of eukaryotic Phosphate homeostasis by inositol Polyphosphate sensor domains. Science 2016, 352, 986-990. [CrossRef]

88. Dong, J.; Ma, G.; Sui, L.; Wei, M.; Satheesh, V.; Zhang, R.; Ge, S.; Li, J.; Zhang, T.E.; Wittwer, C.; et al. Inositol Pyrophosphate $\mathrm{InsP}_{8}$ acts as an intracellular Phosphate signal in Arabidopsis. Mol. Plant 2019, 12, 1463-1473. [CrossRef]

89. Shears, S.B. Inositol pyrophosphates: Why so many Phosphates? Adv. Biol. Regul. 2015, 57, $203-216$. [CrossRef]

90. Zhu, J.; Lau, K.; Puschmann, R.; Harmel, R.K.; Zhang, Y.; Pries, V.; Gaugler, P.; Broger, L.; Dutta, A.K.; Jessen, H.J.; et al. Two bifunctional inositol Pyrophosphate kinases/phosphatases control plant Phosphate homeostasis. eLife 2019, 8, e43582. [CrossRef]

91. Wang, H.; Nair, V.S.; Holland, A.A.; Capolicchio, S.; Jessen, H.J.; Johnson, M.K.; Shears, S.B. Asp1 from Schizosaccharomyces pombe binds a $[2 \mathrm{Fe}-2 \mathrm{~S}]^{2+}$ cluster which inhibits inositol Pyrophosphate 1-phosphatase activity. Biochemistry 2015, 54, 6462-6474. [CrossRef]

92. Sheard, L.B.; Tan, X.; Mao, H.; Withers, J.; Ben-Nissan, G.; Hinds, T.R.; Kobayashi, Y.; Hsu, F.F.; Sharon, M.; Browse, J.; et al. Jasmonate perception by Inositol-Phosphate-potentiated COI1-JAZ co-receptor. Nature 2010, 468, 400-405. [CrossRef] [PubMed]

93. Tan, X.; Calderon-Villalobos, L.I.; Sharon, M.; Zheng, C.; Robinson, C.V.; Estelle, M.; Zheng, N. Mechanism of auxin perception by the TIR1 ubiquitin ligase. Nature 2007, 446, 640-645. [CrossRef]

94. Laha, D.; Johnen, P.; Azevedo, C.; Dynowski, M.; Weiß, M.; Capolicchio, S.; Mao, H.; Iven, T.; Steenbergen, M.; Freyer, M.; et al. VIH2 regulates the synthesis of Inositol Pyrophosphate $\mathrm{InsP}_{8}$ and Jasmonate-dependent defenses in Arabidopsis. Plant Cell 2015, 27, 1082-1097. [CrossRef] [PubMed]

95. Maeda, Y.; Konishi, M.; Kiba, T.; Sakuraba, Y.; Sawaki, N.; Kurai, T.; Ueda, Y.; Sakakibara, H.; Yanagisawa, S. A NIGT1-centred transcriptional cascade regulates nitrate signalling and incorporates phosphorus starvation signals in Arabidopsis. Nat. Commun. 2018, 9, 1376. [CrossRef]

96. Medici, A.; Szponarski, W.; Dangeville, P.; Safi, A.; Dissanayake, I.M.; Saenchai, C.; Emanuel, A.; Rubio, V.; Lacombe, B.; Ruffel, S.; et al. Identification of molecular integrators shows that nitrogen actively controls the Phosphate starvation response in plants. Plant Cell 2019, 31, 1171-1184. [CrossRef]

97. Huang, T.K.; Han, C.L.; Lin, S.I.; Chen, Y.J.; Tsai, Y.C.; Chen, Y.R.; Chen, J.W.; Lin, W.Y.; Chen, P.M.; Liu, T.Y.; et al. Identification of downstream components of ubiquitin-conjugating enzyme PHOSPHATE2 by quantitative membrane proteomics in Arabidopsis roots. Plant Cell 2013, 25, 4044-4060. [CrossRef]

(C) 2019 by the authors. Licensee MDPI, Basel, Switzerland. This article is an open access article distributed under the terms and conditions of the Creative Commons Attribution (CC BY) license (http://creativecommons.org/licenses/by/4.0/). 